\title{
Relationship between serum 25-hydroxyvitamin D and parathyroid hormone in the search for a biochemical definition of vitamin $D$ deficiency in children
}

\author{
Navoda Atapattu', Nick Shaw' and Wolfgang Högler ${ }^{1}$
}

BACKGROUND: Current guidelines use differing definitions of vitamin $\mathrm{D}$ deficiency based on serum 25-hydroxyvitamin D (25OHD) levels, which complicates clinical decision making on vitamin $\mathrm{D}$ doses used for the prevention and treatment. This study examined the natural relationship between serum $25 \mathrm{OHD}$, parathyroid hormone (PTH), calcium, phosphate, and alkaline phosphatase.

METHODS: Two-hundred and fourteen children routinely admitted without conditions affecting the natural relationship among metabolites, including 17 with radiologically confirmed vitamin D deficiency rickets, were studied. The frequency of abnormal bone metabolites was examined for different 25OHD thresholds.

RESULTS: The best fitting intersection point where PTH levels increased was a $25 \mathrm{OHD}$ level of $34 \mathrm{nmol} / \mathrm{I}\left(R^{2}=0.454 ; 95 \%\right.$ confidence interval: $27-41 \mathrm{nmol} / \mathrm{l})$. Seventy-three and $86 \%$ of the children demonstrated some biochemical abnormality below $25 \mathrm{OHD}$ levels of 41 and $27 \mathrm{nmol} / \mathrm{l}$, respectively. All patients with rickets had $25 \mathrm{OHD}$ levels $<34 \mathrm{nmol} / \mathrm{l}$. The vast majority of children with abnormal bone metabolites had 25OHD levels $<$ $34 \mathrm{nmol} / \mathrm{l}$ and PTH levels $>50 \mathrm{ng} / \mathrm{l}$.

CONCLUSION: Vitamin D deficiency, based on PTH elevation, was best defined by a $25 \mathrm{OHD}$ level of $<34 \mathrm{nmol} / \mathrm{l}$. Because deficient calcium supply often coexists with vitamin D deficiency and both can independently cause nutritional rickets, a threshold for the skeletal effects of vitamin D should not be based purely on $250 \mathrm{HD}$ levels.

V itamin D deficiency and its potential health implications are currently the subject of significant interest and controversy (1-6). However, what defines vitamin D deficiency is still under debate, in particular, in children, where studies are limited. The serum level of 25-hydroxyvitamin D (25OHD) is currently considered to be the most appropriate marker of the vitamin D status of an individual. Until recently, the conventional definition of vitamin $\mathrm{D}$ deficiency was a serum $25 \mathrm{OHD}$ level of $<25 \mathrm{nmol} / \mathrm{l}(<10 \mathrm{ng} / \mathrm{ml})(7-9)$ as this level was associated with rickets or osteomalacia. However, the Pediatric Endocrine Society advocated a 25OHD level of $<37.5 \mathrm{nmol} / \mathrm{l}$ $(<15 \mathrm{ng} / \mathrm{ml})$ to define deficiency and $<50 \mathrm{nmol} / \mathrm{l}(20 \mathrm{ng} / \mathrm{ml})$ to define insufficiency (10). More recently, the Institute of Medicine defined vitamin D sufficiency as a 25OHD level $>50$ $\mathrm{nmol} / \mathrm{l}(20 \mathrm{ng} / \mathrm{ml})(11)$, whereas the Endocrine Society defined deficiency as a $25 \mathrm{OHD}$ level $<50 \mathrm{nmol} / \mathrm{l}(20 \mathrm{ng} / \mathrm{ml})$, and insufficiency as a $25 \mathrm{OHD}$ level of $52.5-72.5 \mathrm{nmol} / \mathrm{l}(21-29 \mathrm{ng} / \mathrm{ml})$, for both adults and children (12).

These cutoff values were often based on adult studies in relation to fracture risk, intestinal calcium absorption, or bone mineral density $(1,2,13-16)$. In addition, metabolic evidence supporting these chosen cutoff levels comes from the observations in adults that serum levels of parathyroid hormone (PTH) increase when serum 25OHD level decreases below a variably defined range of 37.5-75 $\mathrm{nmol} / \mathrm{l}$ (15-30 ng/ml) (14,16-21). Active vitamin D (calcitriol) facilitates absorption of calcium and phosphorous from the gut. Its deficiency reduces calcium absorption and serum calcium levels, triggering greater PTH synthesis through the calcium-sensing receptor. PTH elevation subsequently increases mineral release from bone and indirectly maximizes gut mineral resorption by increasing calcitriol synthesis. Nutritional rickets develops in low calcium intake states when PTH-induced phosphaturia causes a decrease in serum phosphate (22).

In children, a few studies have also demonstrated inverse relationships between 25OHD and PTH (23-30). However, no clear consensus for defining vitamin D deficiency based on these studies has been reached. Similar to adult studies, the deflection point of serum 25OHD at which the serum PTH level increases should inform the definition of sufficiency and deficiency. Therefore, we aimed to determine the level of serum 25OHD where PTH and other biochemical bone metabolites start to derange in a large pediatric cohort.

\section{RESULTS}

The final data set included blood results from 214 children (median (range) age: 9.5 y (0.1-19.2)). Forty-three children had bisphosphonate-naive osteogenesis imperfecta. The remaining population constituted children having blood sampling for a great variety of reasons or conditions. Seventeen patients had radiologically confirmed vitamin $\mathrm{D}$ deficiency rickets. 
Median (range) 25OHD level was $31.3 \mathrm{nmol} / \mathrm{l}(0.5-166.0$ $\mathrm{nmol} / \mathrm{l})$. The best fitting intersection point of the PTH-25OHD two-phase linear regression occurred at a $25 \mathrm{OHD}$ level of 34 $\mathrm{nmol} / \mathrm{l}\left(R^{2}=0.454 ; P<0.001 ; 95 \%\right.$ confidence interval: $27-41$ nmol/l; Figure 1). The frequency of bone metabolic abnormalities was assessed at both the ends of this $95 \%$ confidence interval. Of those children with $25 \mathrm{OHD}$ levels $<41 \mathrm{nmol} / \mathrm{l}, 73.3 \%$ had at least one biochemical derangement with $60,32.5,19.0$, and $17.1 \%$ having hyperparathyroidism $(\mathrm{PTH}>50 \mathrm{ng} / \mathrm{l})$, high alkaline phosphatase (ALP) $(>1,000 \mathrm{U} / \mathrm{l})$, hypophosphatemia $(<1.1 \mathrm{mmol} / \mathrm{l})$, or hypocalcemia $(<2.2 \mathrm{mmol} / \mathrm{l})$, respectively. These numbers increased to $86.1,77.2,40.3,23.5$, and $25.6 \%$ for those with a $25 \mathrm{OHD}$ level of $<27 \mathrm{nmol} / \mathrm{l}$. There was no specific higher 25OHD level that suppressed PTH to normal value in all subjects.

The interrelationships between PTH, 25OHD, calcium, and phosphate are shown in Figure 1. Calcium levels $<2.2 \mathrm{mmol} / \mathrm{l}$ were associated with low $25 \mathrm{OHD}$ and elevated PTH levels (each $P<0.001)$. Similarly, phosphate levels $<1.1 \mathrm{mmol} / 1$ were associated with low calcium $(P<0.001)$ and high ALP $(P=0.018)$ and PTH levels $(P<0.001)$. As expected, 25OHD concentrations $<34 \mathrm{nmol} / \mathrm{l}$ were also associated with low calcium $(P<$ $0.001)$, phosphate $(P=0.004)$, and high ALP levels $(P<0.001)$. Relationships among bone metabolic variables in patients with osteogenesis imperfecta were not different from the rest of the cohort, for the same 25OHD range. The PTH-25OHD relationship was similar among different 25OHD assays (data not shown).

All 17 patients with radiologically confirmed vitamin D deficiency rickets had 25OHD levels $<34 \mathrm{nmol} / \mathrm{l}$ and 16 of 17 (94.1\%) had PTH levels $>50 \mathrm{ng} / \mathrm{l}$. The rickets patient with the highest $25 \mathrm{OHD}(32.5 \mathrm{nmol} / \mathrm{l})$ had already commenced treatment doses of vitamin D for $2 \mathrm{wk}$ at the time of blood sampling. Similarly, $95.2 \%$ of the patients with hypocalcemia, $70.4 \%$ with hypophosphatemia, and $69.5 \%$ with high ALP had $25 \mathrm{OHD}$ levels $<34 \mathrm{nmol} / \mathrm{l}$ and PTH levels $>50 \mathrm{ng} / \mathrm{l}$ (Figure 2).

Overall, $47.2 \%$ of the children in this hospital-based cohort had $25 \mathrm{OHD}$ levels $<34 \mathrm{nmol} / \mathrm{l}, 52.8 \%$ had $25 \mathrm{OHD}$ levels $<$ $37.5 \mathrm{nmol} / \mathrm{l}$, and $65.4 \%$ had $25 \mathrm{OHD}$ levels $<50 \mathrm{nmol} / \mathrm{l}$. The majority of the children had their blood tested during winter (29.9\%) and spring (34.6\%). During winter and spring combined, $57 \%$ of the children had $25 \mathrm{OHD}$ levels $<37.5 \mathrm{nmol} / \mathrm{l}$, as compared with $53 \%$ during summer and autumn combined. Out of the 17 patients with vitamin D deficiency rickets, 6 were diagnosed in spring, 5 each during winter and summer, and 1 in autumn.

\section{DISCUSSION}

This study aimed to identify the serum level of $25 \mathrm{OHD}$ below which the derangements of bone metabolism become detectable in the blood stream, in particular, through an increase in serum PTH. A 25OHD concentration of $34 \mathrm{nmol} / \mathrm{l}$ (95\%
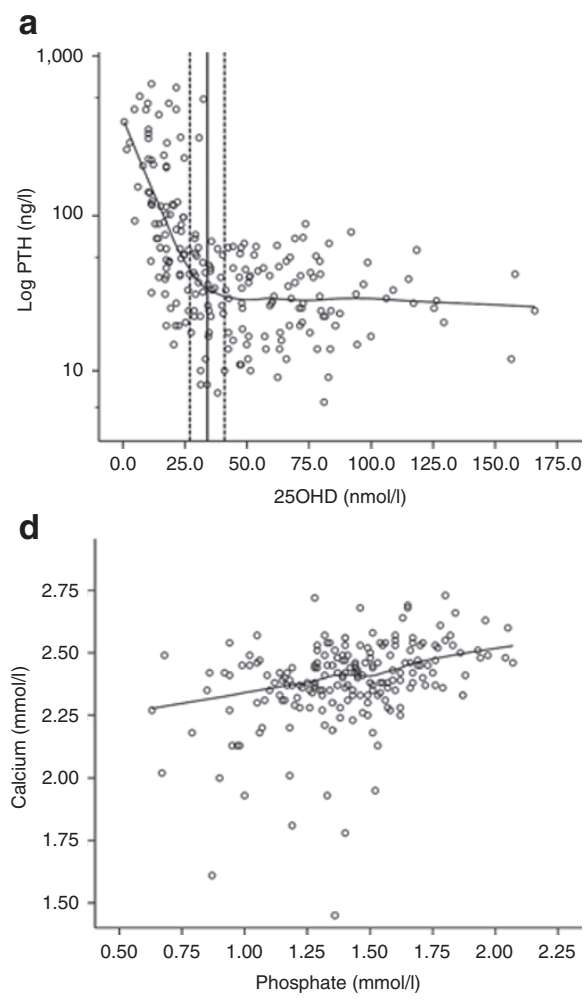

b

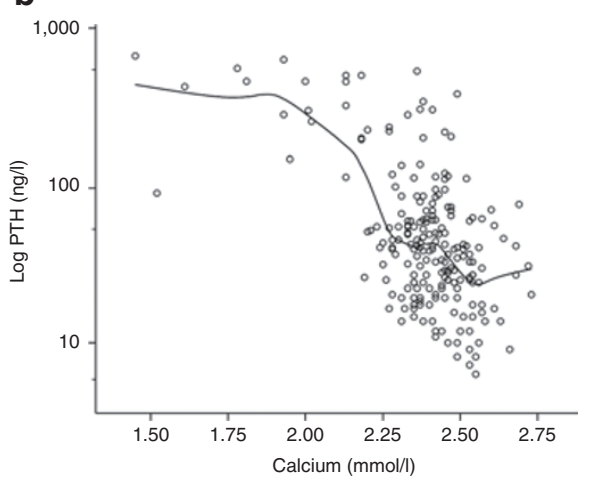

e

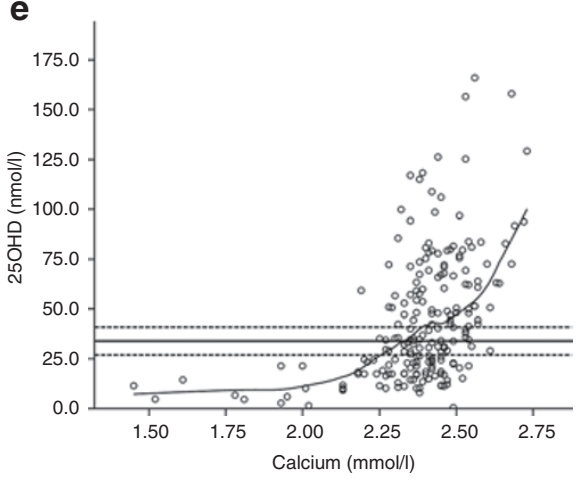

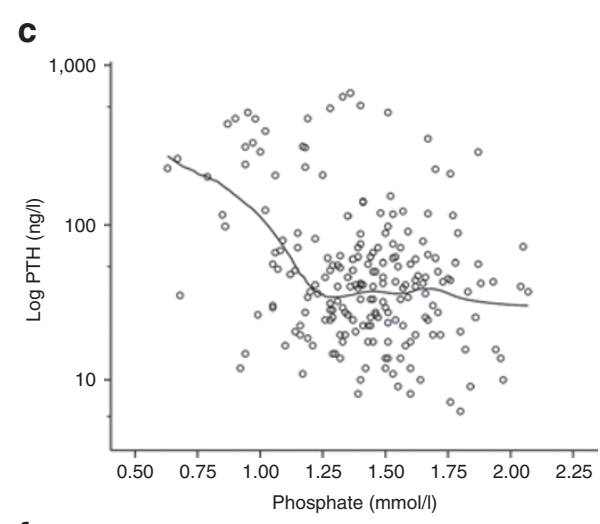

f

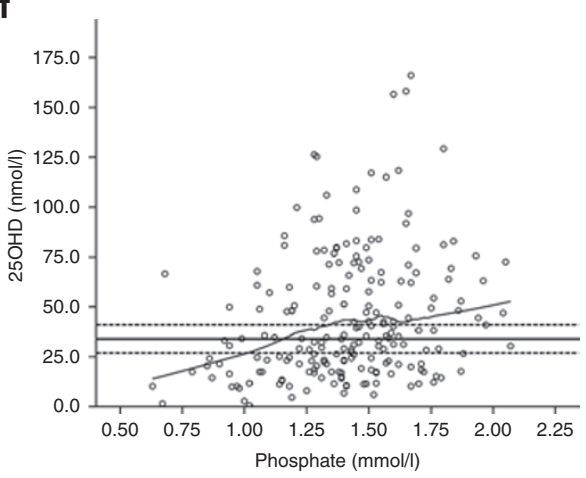

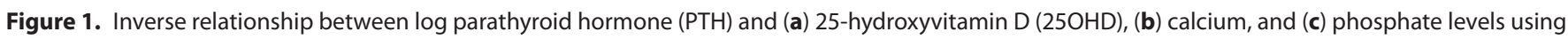
scatter plot smoothing (Loess). (a) PTH levels start to rise as $250 \mathrm{HD}$ levels decrease < $34 \mathrm{nmol} / \mathrm{l}$ (solid line) with $95 \%$ confidence interval: $27-41 \mathrm{nmol} / \mathrm{l}$ (dashed lines). These 250HD thresholds were superimposed on the 25OHD relationship with (e) calcium and (f) phosphate. (d) There was a near-linear relationship between calcium and phosphate. Because phosphate reference values are high during the first weeks of life, two neonates (phosphate levels 2.55 and $2.34 \mathrm{mmol} / \mathrm{l}$ ) were excluded on all phosphate-related figures. 


\section{Articles | Atapattu et al.}

a
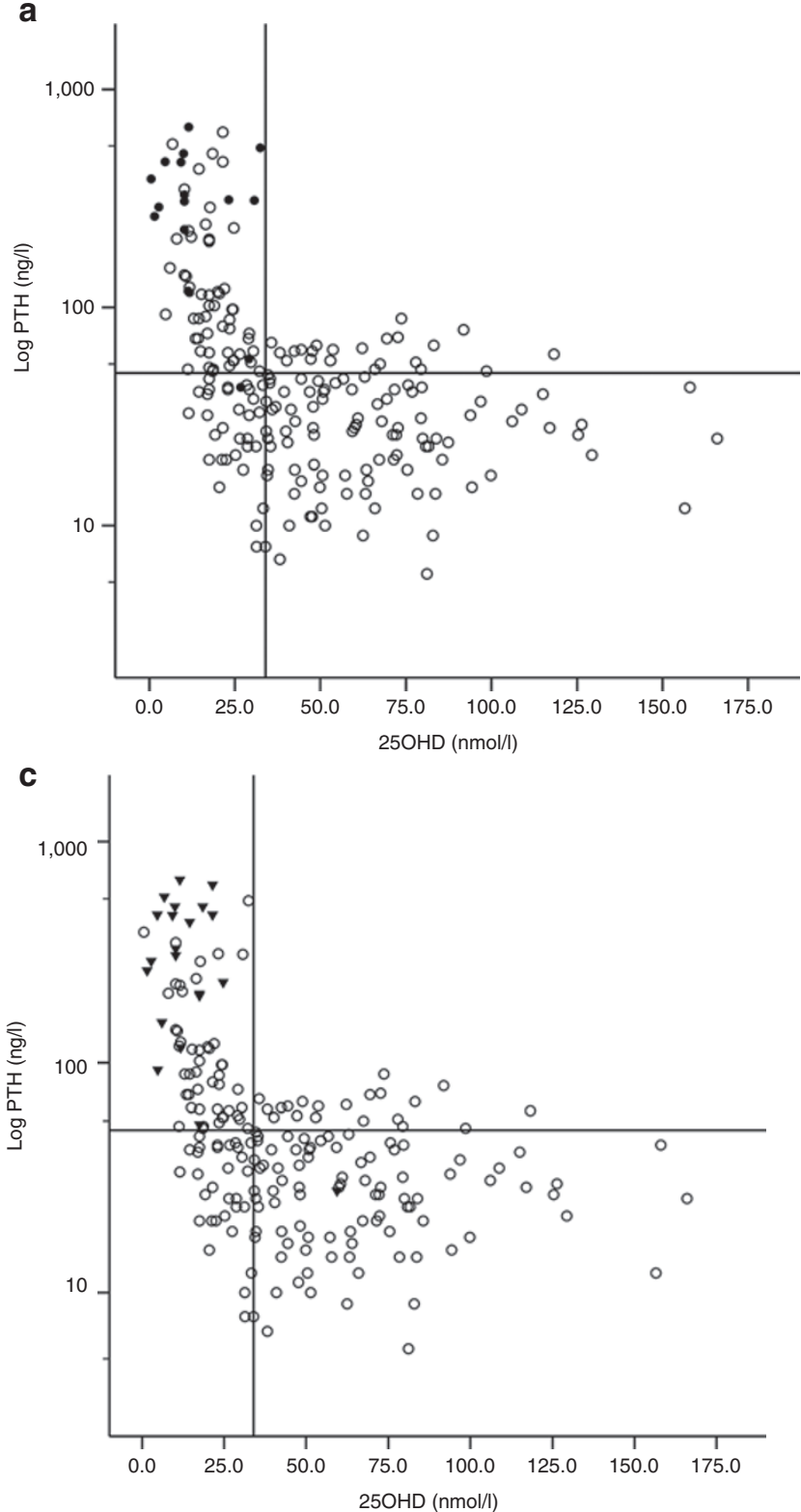

b

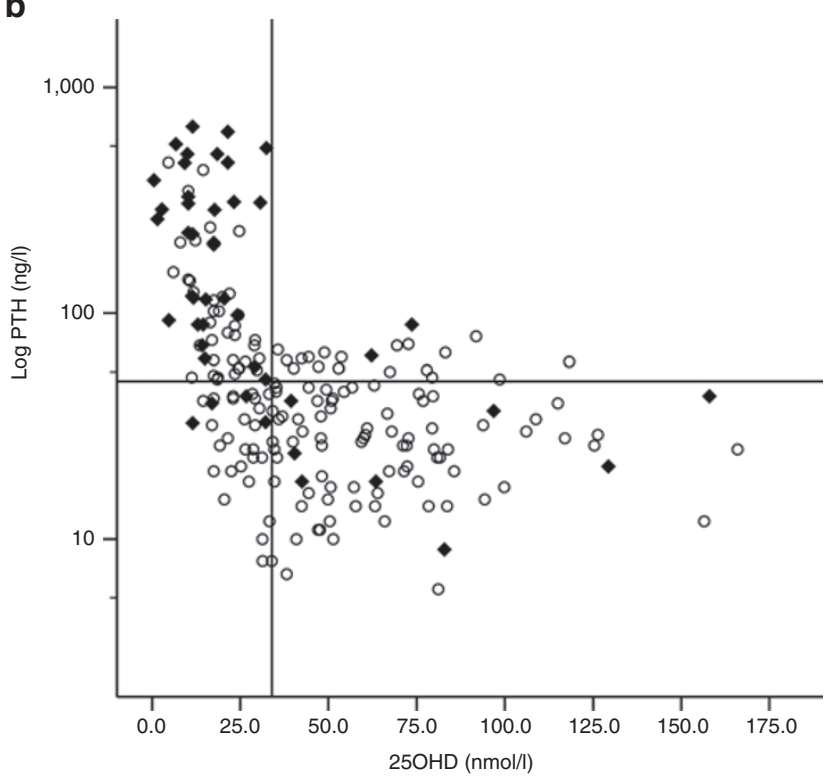

d

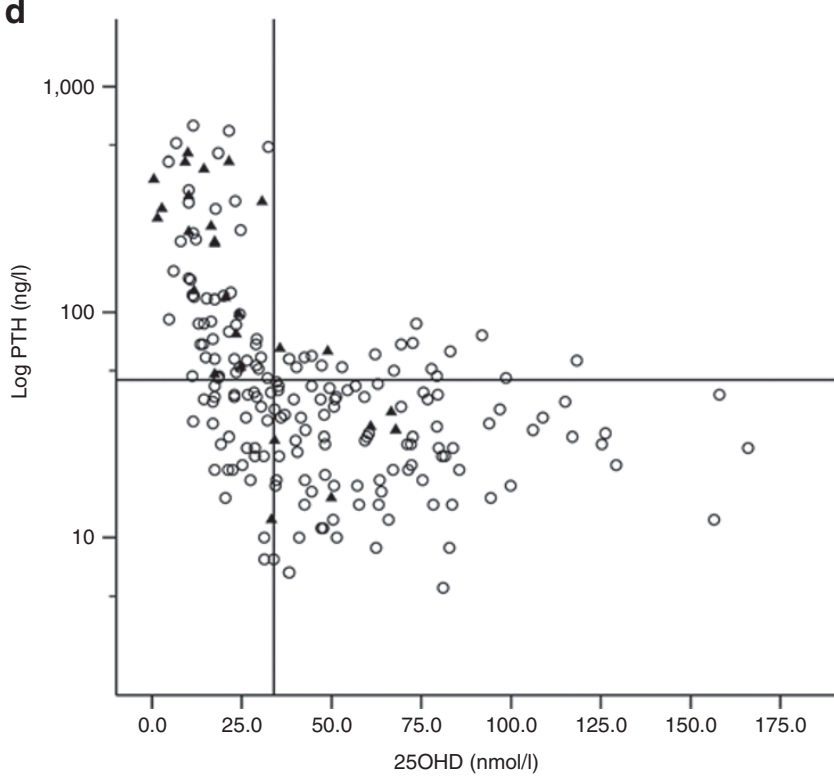

Figure 2. The position of patients with (a) radiologically confirmed rickets (black circles), (b) alkaline phosphatase $>1,000 \mathrm{U} / \mathrm{l}$ (diamonds), (c) calcium < $2.2 \mathrm{mmol} / \mathrm{l}$ (inverted triangles), and (d) phosphate $<1.1 \mathrm{mmol} / \mathrm{I}$ (triangles) on the log parathyroid hormone (PTH)-25-hydroxyvitamin D (25OHD) regression curve, as compared with the rest of the cohort (open circles). The vast majority of patients with abnormal results had PTH levels $>50 \mathrm{ng} / \mathrm{l}$ (horizontal line) and $25 \mathrm{OHD}$ levels $<34 \mathrm{nmol} / \mathrm{l}$ (vertical line).

confidence interval: 27-41) was determined as the deflection point of the PTH-25OHD regression line. This threshold is similar to the $37.5 \mathrm{nmol} / \mathrm{l}$ chosen by the Pediatric Endocrine Society to define vitamin D deficiency (10). However, 25OHD deflection points in pediatric studies vary (23-29), and the relation is sometimes linear rather than deflective (30). For example, in the largest pediatric study to date (29), serum PTH started to increase when $25 \mathrm{OHD}$ levels decreased $<25 \mathrm{nmol} / \mathrm{l}$. Recent large-scale adult studies demonstrate nondeflective PTH-25OHD relationships $(31,32)$ with generally lower PTH levels in children as compared with adults (32).

Ideally, the "optimal" 25OHD threshold should separate abnormal bone metabolism from normal bone metabolism.
Similar to our study, the majority of published patients with vitamin D deficiency rickets have 25OHD levels $<34 \mathrm{nmol} / \mathrm{l}$ (33-36), but nutritional rickets has been reported in children with much greater $25 \mathrm{OHD}$ levels $(22,37,38)$. The variability of 25OHD thresholds and guidelines reflects that an influencing factor exists that determines when nutritional rickets occurs and that factor is calcium intake. The main role of vitamin $\mathrm{D}$ is to act as a mineral supplier by increasing gut calcium absorption. It is important to recognize that even the most severe hereditary form of vitamin D resistance can be successfully treated with calcium supplementation alone. In low vitamin D states, normal calcium supply therefore protects from the development of hyperparathyroidism (20) and rickets (22). On 
the other hand, deficient calcium supply, through poor intake or malabsorption, can lead to rickets even in the presence of perfectly normal $25 \mathrm{OHD}$ levels of up to $140 \mathrm{nmol} / \mathrm{l}(22,37-39)$. It is well recognized that nutritional rickets has pure calcium deficiency with normal vitamin $\mathrm{D}$ on one end of the spectrum and pure vitamin D deficiency with normal calcium intake on the other end $(38,39)$. Hence, a threshold for the development of rickets cannot be based on 25OHD levels alone.

Since calcium intake and especially absorption are not easily measurable in daily practice, distinguishing calcium deficiency alone from vitamin D deficiency is often unachievable. Given that low calcium intake is widespread, especially in teenagers (40), our cohort probably covers the whole spectrum of nutritional rickets. We recognize that $25.7 \%$ of the children in our cohort with $25 \mathrm{OHD}$ levels $<37.5 \mathrm{nmol} / \mathrm{l}$ had entirely normal bone metabolites, which is similar to other pediatric studies $(24,29)$. We speculate that this group may have had normal calcium intake to keep serum PTH within normal limits, as recently described $(20,22)$. Vice versa, elevated PTH levels were observed in children with "normal" 25OHD levels in our cohort, probably because of low calcium intake. Calcium deficiency rickets is not confined to children exposed to extreme undernourishment but, in fact, can be readily observed in western countries (38). Optimizing calcium intake in children and young people may be the more economical public health target rather than aiming for high $25 \mathrm{OHD}$ levels.

Setting very high 25OHD targets to prevent rickets and osteomalacia does not only have economic limitations. Vitamin D supplementation in children with $25 \mathrm{OHD}$ levels $>37.5 \mathrm{nmol} / \mathrm{l}$ does not significantly alter bone metabolism (41), although some effect on PTH is detectable in adults for 25OHD concentrations between 40 and $50 \mathrm{nmol} / \mathrm{l}$ (17). It is worth noting that, while PTH concentrations increase slowly when $25 \mathrm{OHD}$ levels decrease from 75 to $25 \mathrm{nmol} / \mathrm{l}$, these PTH levels are still within normal limits in many, but not all the studies (23-30). Therefore, decreasing PTH from the high-normal range to the low-normal range represents a debatable health outcome. Although we feel that a $25 \mathrm{OHD}$ level of $37.5 \mathrm{nmol} / \mathrm{l}$ (as recommended by the Pediatric Endocrine Society) (10) defines well where the skeletal effects of vitamin D reach a plateau, we recognize that proposed extraskeletal effects of vitamin D may potentially require greater $25 \mathrm{OHD}$ concentrations. However, we believe that there is currently insufficient evidence of such effects upon which to base a definition of vitamin D deficiency.

To the best of our knowledge, this is one of very few pediatric studies which have assessed the interrelationship between PTH, phosphate, ALP, calcium, and vitamin D levels. The inevitable limitation of our study was its retrospective nature, including the lack of data on dietary intake of calcium and vitamin D, calcium absorption, ethnicity, sunshine exposure, and 25OHD assay variation potentially affecting the PTH-25OHD relationship. In addition, our cohort was hospital based and not a healthy group of children, and we have no information on body mass index that can affect vitamin D levels (42). Nevertheless, our cohort is of sufficient size, age range, ethnic, and nutritional diversity to be representative of the typical
UK childhood population who are encountered presenting to hospital.

We conclude that the vast majority of abnormal bone results typical for nutritional rickets is found at 25OHD levels $<34$ $\mathrm{nmol} / \mathrm{l}$ and PTH levels $>50 \mathrm{ng} / \mathrm{l}$. On the basis of our study results and the current evidence in children, we feel that the Pediatric Endocrine Society definition of vitamin D deficiency $(25 \mathrm{OHD} \leq 37.5 \mathrm{nmol} / \mathrm{l})$ and insufficiency $(25 \mathrm{OHD} \leq$ $50 \mathrm{nmol} / \mathrm{l}$ ) is justified. However, defining a threshold for the development of nutritional rickets requires inclusion of calcium intake. Since deficient calcium supply often coexists with vitamin $\mathrm{D}$ deficiency and both can independently cause nutritional rickets, a threshold for the skeletal effects of vitamin $\mathrm{D}$ should not be based purely on 25OHD levels. Given the high prevalence of vitamin D insufficiency and low calcium intake worldwide, important questions remain regarding prevention and supplementation.

\section{METHODS}

Blood results from children (age: 0-19 y) who attended outpatient clinics or were admitted as inpatients to Birmingham Children's Hospital between February 2005 and December 2011 were reviewed as part of a registered clinical management audit. Audits do not require approval by ethics committees, and no informed consent is required for such retrospective audits. Only those children who had simultaneous measurements of serum 25OHD and PTH with plasma calcium, phosphate, and ALP were included in this retrospective audit. The list of patients with the relevant blood results was obtained from the clinical chemistry department, and blood test results were extracted from the hospital's laboratory database. Children with chronic renal failure, chronic liver disease, or any condition that might affect the physiological relation between the measured metabolites (e.g., hypo- or hyperparathyroidism, hypophosphatemic rickets, etc), children on bisphosphonate therapy or taking vitamin D or calcium supplements, and any patients with unclear diagnoses or treatment were excluded. Included in this study were children with bisphosphonate-naive osteogenesis imperfecta (types 1,4), because this collagen disorder does not affect the natural relationship of the bone metabolic variables investigated. Also included were several children with radiologically confirmed vitamin D deficiency rickets, one of whom had started vitamin D supplements at the time of blood sampling. Radiological confirmation of rickets by X-ray was not sought or available in all patients with abnormal bone profile.

Intact PTH was measured using the Immulite 2000 PTH assay (Siemens Healthcare Diagnostics Products, Erlangen, Germany) which is a solid-phase, two-site chemiluminescence enzyme-linked immunosorbent assay. The assay uses two anti-PTH antibodies, a murine monoclonal (PTH 44-48) and a goat polyclonal one (PTH 1-34). Intraassay CVs range from 2.99 to $3.7 \%$ and inter-assay CVs from 4.5 to $7.1 \%$. From 2008 , the analysis of both $25 \mathrm{OHD}_{2}$ and $25 \mathrm{OHD}_{3}$ was performed using liquid chromatography-tandem mass spectrometry, and the total $25 \mathrm{OHD}$ concentration $\left(\mathrm{D}_{2}+\mathrm{D}_{3}\right)$ was calculated. Intra-assay CVs range between 2.5 and $11 \%$ and inter-assay CVs range between 5.8 and $15.5 \%$. Before 2008, the IDS RIA (Immunodiagnostics Systems, Boldon, UK) was used to measure total $25 \mathrm{OHD}$ using a cospecific antibody against both $25 \mathrm{OHD}_{2}$ and $25 \mathrm{OHD}_{3}$, (intra-assay CVs: $5.3-6.1 \%$; inter-assay CVs: $7.3-8.2 \%$ ), except for a 7-month period in which the Nichols Advantage 25(OH)D assay system was used (Nichols Institute Diagnostics, San Clemente, CA) which is based on vitamin D-binding protein recognition and chemiluminescence detection (intra-assay CVs: 2.1-4\%; inter-assay CVs: 4.3-19\%). Plasma calcium, phosphate, and ALP were measured using routine laboratory methods.

\section{Statistical Analysis}

To describe their physiological relationship, circulating serum PTH and 25OHD concentrations were overlaid using the locally weighted regression and scatter plot smoothing (Loess) technique. Interrelationship 
between all measured biochemical variables were plotted using the same technique. To further delineate the deflection point of the PTH $25 \mathrm{OHD}$ curve, a two-phase linear regression was used. Integer 25OHD thresholds from 1 to $50 \mathrm{nmol} / \mathrm{l}$ were tested to determine the best fitting $\left(R^{2}\right)$ intersection point, and the associated $95 \%$ confidence interval was obtained by bootstrapping. The percentage of children with abnormal levels of PTH $(>50 \mathrm{ng} / \mathrm{l})$, phosphate $(<1.1 \mathrm{mmol} / \mathrm{l})$, ALP $(>1,000 \mathrm{U} / \mathrm{l})$, and calcium $(<2.2 \mathrm{mmol} / \mathrm{l})$ were determined for different $25 \mathrm{OHD}$ cutoff levels. In contrast to PTH and calcium levels, phosphate and especially ALP reference levels vary depending on age and growth. Therefore, cutoff levels were chosen which would be regarded abnormal at virtually all ages. Comparison between groups were made using Mann-Whitney test with $P<0.05$ considered significant.

\section{ACKNOWLEDGMENTS}

We are indebted to Peter Nightingale for statistical advice and support.

\section{STATEMENT OF FINANCIAL SUPPORT}

N.A.'s clinical fellowship was funded by a scholarship of the Sri Lankan government, Ferring Pharmaceuticals, Pfizer, and the UK Child Growth Foundation.

\section{Disclosure: The authors declare no conflict of interest.}

\section{REFERENCES}

1. Holick MF. Sunlight and vitamin D for bone health and prevention of autoimmune diseases, cancers, and cardiovascular disease. Am J Clin Nutr 2004;80:Suppl 6:1678S-88S.

2. Holick MF. Vitamin D deficiency. N Engl J Med 2007;357:266-81.

3. Holick MF, Chen TC. Vitamin D deficiency: a worldwide problem with health consequences. Am J Clin Nutr 2008;87:1080S-6S.

4. Zipitis CS, Akobeng AK. Vitamin D supplementation in early childhood and risk of type 1 diabetes: a systematic review and meta-analysis. Arch Dis Child 2008;93:512-7.

5. Wayse V, Yousafzai A, Mogale K, Filteau S. Association of subclinical vitamin D deficiency with severe acute lower respiratory infection in Indian children under 5 y. Eur J Clin Nutr 2004;58:563-7.

6. Fabri M, Stenger S, Shin DM, et al. Vitamin D is required for IFN-gammamediated antimicrobial activity of human macrophages. Sci Transl Med 2011;3:104ra102.

7. Thacher TD, Clarke BL. Vitamin D insufficiency. Mayo Clin Proc 2011;86:50-60.

8. Prentice A, Goldberg GR, Schoenmakers I. Vitamin D across the lifecycle: physiology and biomarkers. Am J Clin Nutr 2008;88:500S-6S.

9. Looker AC, Dawson-Hughes B, Calvo MS, Gunter EW, Sahyoun NR. Serum 25-hydroxyvitamin D status of adolescents and adults in two seasonal subpopulations from NHANES III. Bone 2002;30:771-7.

10. Misra M, Pacaud D, Petryk A, Collett-Solberg PF, Kappy M; Drug and Therapeutics Committee of the Lawson Wilkins Pediatric Endocrine Society. Vitamin D deficiency in children and its management: review of current knowledge and recommendations. Pediatrics 2008;122:398-417.

11. Ross AC, Manson JE, Abrams SA, et al. The 2011 report on dietary reference intakes for calcium and vitamin $\mathrm{D}$ from the Institute of Medicine: what clinicians need to know. J Clin Endocrinol Metab 2011;96:53-8.

12. Holick MF, Binkley NC, Bischoff-Ferrari HA, et al.; Endocrine Society. Evaluation, treatment, and prevention of vitamin D deficiency: an Endocrine Society clinical practice guideline. J Clin Endocrinol Metab 2011;96:1911-30.

13. Heaney RP. Functional indices of vitamin $\mathrm{D}$ status and ramifications of vitamin D deficiency. Am J Clin Nutr 2004;80:Suppl 6:1706S-9S.

14. Chapuy MC, Preziosi P, Maamer M, et al. Prevalence of vitamin D insufficiency in an adult normal population. Osteoporos Int 1997;7:439-43.

15. Heaney RP, Dowell MS, Hale CA, Bendich A. Calcium absorption varies within the reference range for serum 25-hydroxyvitamin D. J Am Coll Nutr 2003;22:142-6.

16. Vieth R, Ladak Y, Walfish PG. Age-related changes in the 25-hydroxyvitamin $\mathrm{D}$ versus parathyroid hormone relationship suggest a different reason why older adults require more vitamin D. J Clin Endocrinol Metab 2003;88:185-91.

17. Malabanan A, Veronikis IE, Holick MF. Redefining vitamin D insufficiency. Lancet 1998;351:805-6.
18. Lips P. Vitamin D deficiency and secondary hyperparathyroidism in the elderly: consequences for bone loss and fractures and therapeutic implications. Endocr Rev 2001;22:477-501.

19. Thomas MK, Lloyd-Jones DM, Thadhani RI, et al. Hypovitaminosis D in medical inpatients. N Engl J Med 1998;338:777-83.

20. Steingrimsdottir L, Gunnarsson O, Indridason OS, Franzson L, Sigurdsson G. Relationship between serum parathyroid hormone levels, vitamin D sufficiency, and calcium intake. JAMA 2005;294:2336-41.

21. Tangpricha V, Pearce EN, Chen TC, Holick MF. Vitamin D insufficiency among free-living healthy young adults. Am J Med 2002;112: 659-62.

22. Aggarwal V, Seth A, Aneja S, et al. Role of calcium deficiency in development of nutritional rickets in Indian children: a case control study. J Clin Endocrinol Metab 2012;97:3461-6.

23. Gordon CM, DePeter KC, Feldman HA, Grace E, Emans SJ. Prevalence of vitamin D deficiency among healthy adolescents. Arch Pediatr Adolesc Med 2004;158:531-7.

24. Outila TA, Kärkkäinen MU, Lamberg-Allardt CJ. Vitamin D status affects serum parathyroid hormone concentrations during winter in female adolescents: associations with forearm bone mineral density. Am J Clin Nutr 2001;74:206-10.

25. Guillemant J, Cabrol S, Allemandou A, Peres G, Guillemant S. Vitamin D-dependent seasonal variation of PTH in growing male adolescents. Bone 1995;17:513-6.

26. Guillemant J, Taupin P, Le HT, et al. Vitamin D status during puberty in French healthy male adolescents. Osteoporos Int 1999;10:222-5.

27. El-Hajj Fuleihan G, Nabulsi M, Choucair M, et al. Hypovitaminosis D in healthy schoolchildren. Pediatrics 2001;107:E53.

28. Hill TR, Cotter AA, Mitchell S, et al. Vitamin D status and parathyroid hormone relationship in adolescents and its association with bone health parameters: analysis of the Northern Ireland Young Heart's Project. Osteoporos Int 2010;21:695-700.

29. Marwaha RK, Tandon N, Reddy DR, et al. Vitamin D and bone mineral density status of healthy schoolchildren in northern India. Am J Clin Nutr 2005;82:477-82.

30. Hill KM, McCabe GP, McCabe LD, Gordon CM, Abrams SA, Weaver CM. An inflection point of serum 25-hydroxyvitamin D for maximal suppression of parathyroid hormone is not evident from multi-site pooled data in children and adolescents. J Nutr 2010;140:1983-8.

31. Sai AJ, Walters RW, Fang X, Gallagher JC. Relationship between vitamin D, parathyroid hormone, and bone health. J Clin Endocrinol Metab 2011;96:E436-46.

32. Valcour A, Blocki F, Hawkins DM, Rao SD. Effects of age and serum 25-OH-vitamin D on serum parathyroid hormone levels. J Clin Endocrinol Metab 2012;97:3989-95.

33. Robinson PD, Högler W, Craig ME, et al. The re-emerging burden of rickets: a decade of experience from Sydney. Arch Dis Child 2006;91:564-8.

34. Ladhani S, Srinivasan L, Buchanan C, Allgrove J. Presentation of vitamin D deficiency. Arch Dis Child 2004;89:781-4.

35. Hatun S, Ozkan B, Orbak Z, et al. Vitamin D deficiency in early infancy. J Nutr 2005;135:279-82.

36. Mughal MZ. Rickets. Curr Osteoporos Rep 2011;9:291-9.

37. Balasubramanian K, Rajeswari J, Gulab, et al. Varying role of vitamin D deficiency in the etiology of rickets in young children vs. adolescents in northern India. J Trop Pediatr 2003;49:201-6.

38. DeLucia MC, Mitnick ME, Carpenter TO. Nutritional rickets with normal circulating 25-hydroxyvitamin D: a call for reexamining the role of dietary calcium intake in North American infants. J Clin Endocrinol Metab 2003;88:3539-45.

39. Thacher TD, Fischer PR, Strand MA, Pettifor JM. Nutritional rickets around the world: causes and future directions. Ann Trop Paediatr 2006;26:1-16.

40. Nicklas TA. Nutrient profiling: the new environment. J Am Coll Nutr 2009;28:416S-20S.

41. Docio S, Riancho JA, Pérez A, Olmos JM, Amado JA, GonzálezMacías J. Seasonal deficiency of vitamin D in children: a potential target for osteoporosis-preventing strategies? J Bone Miner Res 1998;13: $544-8$.

42. Earthman CP, Beckman LM, Masodkar K, Sibley SD. The link between obesity and low circulating 25-hydroxyvitamin D concentrations: considerations and implications. Int J Obes (Lond) 2012;36:387-96. 